\title{
Конструирование смыслов поисковой работы в России: лейтмотивы властей и участников экспедиций ${ }^{1}$
}

\author{
Н.В. ГОНЧАРОВА*, И.Г. ЯСАВЕЕВ**
}

\begin{abstract}
*Наталья Владимировна Гончарова - кандидат социологических наук, научный сотрудник, Центр молодежных исследований, Национальный исследовательский университет «Высшая школа экономики» в Санкт-Петербурге. Адрес: 192148, Санкт-Петербург, ул. Седова, д. 55, корп. 2. E-mail: nata_gonch@mail.ru

**Искэндэр Габдрахманович Ясавеев - доктор социологических наук, старший научный сотрудник, Центр молодежных исследований, Национальный исследовательский университет «Высшая школа экономики» в Санкт-Петербурге. Адрес: 192148, Санкт-Петербург, ул. Седова, д. 55, корп. 2. E-mail: yasaveyev@gmail.com
\end{abstract}

Цитирование: Гончарова Н.В., Ясавеев И.Г. (2020) Конструирование смыслов поисковой работы в России: лейтмотивы властей и участников экспедиций // Мир России. T. 29. № 1. C. 153-173. DOI: 10.17323/1811-038X-2020-29-1-153-173

В статье исследуются смысль поисковой работы в России по обнаружению останков и установлению имен незахороненных солдат Второй мировой войны. Эти смыслы формируются не только участниками экспедиций, но и российскими властями, поддерживающими поисковиков. В работе анализируются высказывания президентов России, материаль включенного наблюдения в поисковых экспедициях, интервью с их участниками и тексты, написанные поисковиками в виде книг, рассказов, песен и постов в социальных сетях. Власть дискурсивно встраивает поисковое движение в патриотическое воспитание граждан, формулируя смыслы поисковой работы в контексте милитаризованного патриотизма. Лейтмотивами властной риторики о поиске солдат являются патриотизм, героизм, воспитание, гордость за Отечество и укрепление страны. Поисковая работа представляется президентом России как демонстрирующая «настоящий патриотизм»,

\footnotetext{
1 Статья подготовлена по материалам исследования, которое проводится за счет гранта Российского научного фонда (проект «Созидательные поля межэтнического взаимодействия и молодежные культурные сцены российских городов» № 15-18-00078) в Центре молодежных исследований НИУ ВШЭ - Санкт-Петербург. Основные положения статьи были впервые представлены на XX Апрельской научной конференции в НИУ ВШЭ (9-12 апреля 2019 г.).

Авторы благодарны О.А. Доброштан за полевое исследование; поисковикам - за их работу, открытость и доверие; сотрудникам Всероссийского информационно-поискового центра «Отечество» - за помощь с доступом к книгам, написанным поисковиками.
} 
который заключается в защите страны с оружием в руках и самопожертвовании. Между тем лейтмотивом высказываний поисковиков о своей работе является несправедливость по отношению к незахороненным солдатам. В связи с этим часть поисковиков критически высказывается о воспитательном эффекте поисковой работьл. Со стремлением восстановить справедливость связана главная для участников экспедиций идея поисковой работы - оповещение родственников о судьбе пропавщего без вести солдата. Завершенный поиск способствует пониманию трагедии семей, потерявших на войне своих близких. Государственной милитаристской риторике дискурсивно противопоставляется проблематизация войны, основанная на опыте поисковой работы.

Ключевые слова: поисковое движение, поисковики, власть, патриотизм, риторика, молодежь, война, работа памяти

\section{Введение}

В 1980-е гг. в СССР началось движение, участники которого ищут незахороненных солдат Второй мировой войны, собирают их останки для погребения на воинских мемориалах, пытаются установить имена погибших для оповещения их родственников.

Более тысячи российских поисковых отрядов ${ }^{2}$ работают там, где во времена Второй мировой войны шли бои: в Калининградской, Мурманской, Ленинградской, Псковской, Новгородской, Вологодской, Тверской, Смоленской, Калужской, Московской, Рязанской, Брянской, Тульской, Орловской, Липецкой, Курской, Белгородской, Воронежской, Волгоградской, Ростовской, Сахалинской областях, в Карелии, Калмыкии, Карачаево-Черкессии, Кабардино-Балкарии, Северной Осетии - Алании, Ингушетии, Чеченской Республике, Краснодарском и Ставропольском краях, а также в Крыму и Республике Беларусь.

В 1990-е и 2000-е гг. поисковое движение не получало ощутимой поддержки со стороны российских властных структур, чья роль сводилась в лучшем случае к помощи с организацией похорон солдат, однако в 2010-е гг. ситуация начала меняться: российские власти все чаще стали обращать внимание на работу участников поисковых экспедиций. Президенты России Д.А. Медведев и В.В. Путин несколько раз встречались с поисковиками в рамках мероприятий «Вахта Памяти» (поисковых сезонов) и заявляли о своей поддержке. В апреле 2013 г. была создана общественная организация «Поисковое движение России», объединившая региональные штабы поисковиков. Поисковые отряды и объединения регулярно получают президентские гранты, гранты Росмолодежи и Роспатриотцентра. Как сообщалось на встрече поисковиков с президентом России в Курске, поддержку из Фонда президентских грантов получили в 2017 и 2018 г. 45 поисковых объединений из 30 регионов [Путин (2) 2018].

В последние годы российская власть не только поддерживает и награждает поисковиков [Указ Президента 2013], но и активно формулирует смыслы поиско-

\footnotetext{
2 На сайте Поискового движения России указано, что оно объединяет 1428 поисковых отрядов [Общероссийское общественное движение по увековечению памяти погибших 2019].
} 
вой работы. Президенты России, встречаясь с участниками отрядов, неоднократно давали разъяснения о значении их поисков. Между тем сами поисковики постоянно формируют и проговаривают эти смыслы, отвечая самим себе и другим на вопросы о том, для чего они тревожат останки солдат, «поднимают» ${ }^{3}$ их и хоронят. Исследовательские вопросы, возникающие в связи с этим: каковы лейтмотивы риторики о поиске погибших солдат, используемой властями и участниками экспедиций; в каких контекстах они формируются; каковы различия между смыслами поисковой работы, создаваемыми властями и самими поисковиками?

С недавнего времени конструирование смыслов поисковой работы находится в фокусе внимания исследователей. Йоханна Далин [Dahlin 2017; Dahlin 2018], изучая поисковые экспедиции методом включенного наблюдения, определяет их как эмоциональную работу и работу памяти: «Зрелищный образ войны, показываемый во время празднования Дня Победы, противопоставляется ужасным образам, обнаруживаемым в лесах и болотах. < ..> Цель распространения информации поисковиками заключается не только в том, чтобы распространять знание о войне, но и расширить официальную картину горькими примерами, свидетельствующими об очень высокой цене этой победы. <.. > Поисковая работа дает "из первых рук" опыт войны и потерь» [Dahlin 2018]. Также Й. Далин исследует сложное отношение между патриотизмом и поисковым движением [Dahlin 2017]: по ее мнению, центральным пунктом патриотизма является лояльность к государству и его институтам. Однако поисковиков отличает двойственность позиции: с одной стороны, для них характерна такая лояльность, с другой, причиной возникновения поискового движения стало невыполнение самим государством обязательств по отношению к погибшим за него солдатам [Dahlin 2017, p. 1086]. Далин пишет о конфликте в поисковом движении между лояльностью и критикой государства, о напряженности и внутренней амбивалентности по отношению к войне и стране. «Предательство по отношению к тем, кто остался на полях сражений, выдвигается [поисковым движением] на передний план» [Dahlin 2017, p. 1086]. Тем не менее Й. Далин, основываясь на анализе сборника статей, написанных руководителями поисковых отрядов и объединений о вкладе движения в патриотическое воспитание, утверждает, что большинство поисковиков придерживается той версии патриотизма, которая может сосуществовать с определенной долей критики государства [Dahlin 2017, p. 1087].

Противоречие между патриотизмом и поисковым движением ранее проанализировала Марлен Ларуэль, изучавшая патриотические молодежные клубы в России. Ларуэль цитирует слова одной из информанток о том, что возглавляемый ею поисковый отряд получает муниципальное финансирование в рамках программы патриотического воспитания, но молодые люди, участники отряда, «становятся

\footnotetext{
3 Поисковики обычно не используют слово «эксгумация», поскольку оно является формальным и предполагает извлечение похороненных тел. Вместо выражения «эксгумировать останки» поисковики говорят, что они «поднимают солдат». Вместе с тем слово «эксгумация» используется в поисковых документах (протоколах раскопа и эксгумации), заполняемых в ходе поисковых работ. Из других особенностей языка поисковиков можно отметить термин «верховой», обозначающий останки солдата, которые лежат на небольшой глубине, под дерном, в отличие от останков в воронках, санитарных и боевых захоронениях, и выражение «прочитать медальон», означающее прочтение бумажного вкладыша смертного медальона (эбонитовой капсулы). В отношении погребения найденных солдат обычно используется слово «захоронение», хотя среди поисковиков обсуждалась его неуместность в связи с применением в других контекстах (захоронение ядерных отходов и пр.).
} 
непатриотичными», когда понимают, что государство не захоронило всех тех, кто погиб за страну [Laruelle 2015, p. 9]. Она отмечает существование значительного разрыва между патриотическими нарративами и практиками участников клубов, включая поисковые отряды, и нарративами и практиками, ожидаемыми Кремлем, согласно которым «настоящий патриот» активно поддерживает режим, верит в государство, ответственное за общее благо, следует в своей повседневной жизни рекомендациям власти и потенциально готов воевать за страну [Laruelle 2015, p. 9]. Между тем участники патриотических клубов наполняют патриотизм своим собственным, зачастую критическим по отношению к армии и государству содержанием, касающимся не страны вообще, а малой родины. Большинство, пишет М. Ларуэль, «критикует задаваемый Кремлем официальный нарратив как разновидность “поверхностного патриотизма” (ура-патриотизма), никогда не становящегося конкретным» [Laruelle 2015, p. 24].

Исследователи указывают на отсутствие определения патриотизма в государственной риторике: «Само слово “патриотизм” не расшифровывается, а постулируется как нечто очевидное, само собой разумеющееся, общее знание» [Омельченко 2012, с. 275]. Ларуэль отмечает, что попытки Кремля наполнить «патриотизм» конкретным идеологическим содержанием оставались ограниченными, по крайней мере, до момента возникновения украинского кризиса, поскольку власти стремились к достижению социального консенсуса: «В таком прочтении почти свободный от содержания и деполитизированный патриотизм является победой для режима Путина, и патриотические клубы, хотя и заявляли о своей независимости от государственных прерогатив, являлись в некотором смысле его невольными и скрытыми союзниками» [Laruelle 2015, p. 25].

Следует отметить, что в течение третьего президентского срока В.В. Путина со стороны российских властей произошли переопределение и конкретизация патриотизма, который начиная с 2012 г. становится одним из лейтмотивов властной риторики в отношении молодежи и предлагается властями в качестве национальной идеи вместо прежней идеи «обеспечения конкурентоспособности страны во всех сферах, во всех областях» [Путин 2003]. Смысл патриотизма смещается властями от «любви к Отечеству» к готовности защищать государство [Ясавеев 2016], в связи с чем уместен вопрос: являются ли поисковики союзниками властей в отстаивании такой милитаризованной версии патриотизма?

Поисковая работа может описываться в терминах официальной и коллективной памяти, и противоречия между этими видами памяти отмечаются многими исследователями ${ }^{4}$. В нашей статье используется предложенное Питером Ибаррой и Джоном Китсьюзом конструкционистское понятие лейтмотивов, которые понимаются как «повторяющиеся тематические элементы и фигуры речи, в сжатой форме выражающие или высвечивающие главный аспект или динамику социальной проблемы» [Ибарра, Китсьюз 2007, с. 93]. Исследование, основанное на идее лейтмотивов, позволяет сосредоточиться на том, каким образом развиваются и обретают «точную настройку» термины дискурса социальных проблем и как определяется их символический подтекст [Ибарра, Китсьюз 2007, с. 96]. Такой анализ дает воз-

\footnotetext{
4 В частности, Елена Рождественская и Виктория Семенова противопоставляют официальной памяти как ресурсу и продукту государственного манипулирования (война в Афганистане) коллективную память «афганцев» [Рождественская, Семенова 2011].
} 
можность понять действия участников. Хотя построение смыслов поисковой работы обычно не предполагает конструирование социальной проблемы (выдвижение требований изменить ситуацию), изучение лейтмотивов, на наш взгляд, позволяет выявить создаваемые властями и участниками поиска смысловые конструкции.

\section{Методология}

Эмпирическую базу исследования составили выступления президентов России о поисковой работе, материалы включенного наблюдения в экспедициях, интервью с участниками поисковых отрядов и тексты, опубликованные в виде постов в социальных сетях, воспоминаний, рассказов и песен поисковиков 5 .

Высказывания президентов России В.В. Путина и Д.А. Медведева были обнаружены на сайте Кремля ${ }^{6}$ по ключевым словам «поисковики», «поисковое движение», «поисковый отряд», «поисковая работа», «поисковая экспедиция», «поисковая деятельность», «Вахта Памяти». После исключения сообщений о поисковых системах в Интернете, поиске пропавших людей участниками отряда «Лиза Алерт», работах на местах чрезвычайных ситуаций образовалась совокупность из 46 сообщений с заявлениями российских президентов о поисковой работе на местах боев Второй мировой войны. Хронологические рамки исследования властной риторики - с 2000 г. ${ }^{7}$ (начала первого президентского срока В.В. Путина) до июня 2019 г.

Включенное наблюдение проводилось Н.В. Гончаровой и сотрудником Научно-исследовательского центра «Регион» (Ульяновск) О.А. Доброштан в поисковой экспедиции «Любань» в 2017 и 2018 гг; общее число дней наблюдения - 21 (роль исследователей при проведении включенного наблюдения не скрывалась). С участниками поисковых отрядов Н.В. Гончаровой и О.А. Доброштан было проведено 24 глубинных интервью; возраст информантов - от 18 до 30 лет; средняя продолжительность интервью - около двух часов. Одновременно с включенным наблюдением в экспедиции «Любань» в 2017 г. сотрудником Центра молодежных исследований НИУ ВШЭ - Санкт-Петербург Дмитрием Омельченко был снят документальный фильм, включающий в себя интервью с поисковиками [Омельченко 2017].

Опубликованные тексты поисковиков (очерки, воспоминания, рассказы) были найдены в библиотеке Всероссийского информационно-поискового центра «Отечество» и в сети Интернет. Работа с библиотекой «Отечества», находящейся в Казани, позволила изучить книги, написанные поисковиками [Котилевский 2004; Черепанов 2006; Иванова 2012; Комендант «Долины смерти» 2013; Савельев,

\footnotetext{
5 Авторы исследования включены в поисковую работу в качестве участников экспедиций: Н.В. Гончарова с 2017 г. в составе отряда «Снежный десант КФУ»; И.Г. Ясавеев - с 1993 г. участник отряда «Снежный десант истфака КГУ - гимназии 122» (Казань). При проведении исследования авторы разграничивали позиции участника и аналитика и прилагали усилия для того, чтобы их поисковая работа, возникающие эмоции, переживания и отношение к поиску не влияли на исследовательские результаты.

6 www.kremlin.ru

7 Закон РФ N 4292-1 «Об увековечении памяти погибших при защите Отечества», включающий в себя раздел о поисковой работе и определяющий ее правовые основания, был подписан Президентом России Борисом Ельциным 14 января 1993 г.
} 
Пицко 2015; Щербина 2016; Савельев 2017; Берестов 2018]. Тексты песен поисковиков изучались по видео- и аудиозаписям, сделанным в экспедициях, и аудиозаписям на CD-диске, изданном Поисковой экспедицией «Долина» (Великий Новгород) [Неоконченная война 2005].

В качестве лейтмотивов, относящихся к смыслам поисковой работы, в ходе анализа текстов выделялись неоднократно встречающиеся конструкции, используемые для обозначения сущности поиска, его целей и необходимости (кодирование осуществлялось вручную).

\section{Властная риторика о поисковой работе}

Высказывания В.В. Путина о поисковой работе на местах боев Второй мировой войны в течение его первых президентских сроков (2000-2004, 2004-2008 гг.) немногочисленны: на сайте Кремля удалось обнаружить лишь два замечания, относящиеся к 2004 и 2005 гг. и выделяющиеся своим бюрократическим стилем «эффективная организация поисковых и военно-патриотических мероприятий», «эффективность этих мер», «должная организация этой работы». Внимание к поисковикам стало расти начиная с президентского срока Д.А. Медведева (2008-2012 гг.): по три высказывания о поисковиках было сделано в 2009 и 2010 гг. и одно в 2011 г. Д.А. Медведев говорил об их работе как о «настоящем» или «истинном патриотизме» в противоположность «показному» [Медведев (1) 2009; Медведев 2010].

Заметный поворот к поисковикам произошел в середине третьего президентского срока В.В. Путина: начиная с 2015 г. президент стал значительно чаще встречаться с участниками поисковых экспедиций и обсуждать их действия. Из 46 высказываний президентов России о поисковой работе, обнаруженных на сайте Кремля, 28 приходятся на период начиная с 2015 г., что может быть объяснено кризисом на Украине, интенсивным использованием, переопределением и милитаризацией идеи патриотизма. По мнению Путина, поисковая работа демонстрирует «настоящий патриотизм», включающий в себя защиту страны с оружием в руках и самопожертвование:

«Члены поисковых отрядов собирают людей, молодежь вокруг действительно важных, определяюших изенностей, показывают, что такое настоящий патриотизм, что на деле означает знать и уважать родную историю, гордиться родной страной и ратной славой предков» [Путин (1) 2015].

«Здесь прямо, в домовладениях, что называется, к сожалению, до сих пор находят останки наших солдат. И что на меня произвело особое впечатление сейчас: с оружием в руках, повернутые в сторону противника, - они никуда назад не отступали, смерть их застала с оружием в руках в бою, когда они шли вперед, наступали. Именно такое отношение к Родине, к Отечеству - в характере нашего народа. И именно это мы должны зафиксировать на долгие-долгие годы вперед для всех будущих поколений. Потому что это, собственно говоря, и есть то, на чем всегда стояла Россия, - на самопожертвовании, на любви к Отечеству» [Путин (1) 2018]. 
«Действующая программа [патриотического воспитания граждан] заканчивается в 2020 году. Участие поисковиков в разработке и реализации этого документа имеет серьезную, особую значимость. Именно вы, уважаемье друзья, открываете ранее неизвестные события и факты нашей ратной истории, возвращаете стране имена, судьбы ее героев, те великие примеры подлинного патриотизма, на которых и должны расти, воспитываться новая генерация наших граждан, новые поколения» [Путин 2019].

В другом тексте, не связанном с поисковой работой, президент заявил о предрасположенности граждан России (в отличие от других стран) «жизнь свою отдать за Отечество» [Путин (3) 2018].

Повторяющимися элементами властной риторики о поисковой работе являются «воспитание» и «гордость за Отечество»:

«То, что делают почсковики, это, конечно, очень благородная, важная работа. Она, конечно, прежде всего, направлена на то, чтобы отдать дань уважения воинам, которые защищали Отечество, но она направлена и на воспитание сегодняшнего и будущих поколений в духе преданности и любви к Отечеству, что чрезвычайно важно для будущего нашей страны. <..> То, чем вы занимаетесь, - поисковые отряды, вообще все движение, - она ведь, эта деятельность, и результаты ее работы, как это ни покажется странным, не нужна тем, о ком вы заботитесь. Этих людей уже давно нет, они ушли из жизни, они погибли. Эта работа нужна живущим сегодня и будущим поколениям. Это абсолютно очевидная вещь. Это нужно для воспитания нашего общества в любви и почитании тех, кто отдал за страну, за будущее поколение, в том числе за нас с вами, самое дорогое, что есть у человека, - жизнь свою. Только такое общество, которое имеет такой внутренний моральный стержень, оно имеет шансы на будущее и на позитивное развитие. В этом основной смысл и главный смысл, конечно, вашей работыл.» [Путин (2) 2018].

«Привлекая школьников и студентов к практической, “полевой” работе, вы воспитываете единомышленников, которые разделяют общие высокие моральные ценности, гордятся Отечеством, предками, их боевыми и трудовыми свершениями, стремятся внести личный вклад в увековечение памяти павших советских воинов» [Путин (2) 2017].

«По зову сердца поисковики ухаживают за воинскими мемориалами и захоронениями, восстанавливают имена павших, искренне заботятся о том, чтобы не прерывалась связь времен, чтобы молодежь знала историю своего Отечества и гордилась ею» [Путин 2014].

В президентских высказываниях о поисковой работе неоднократно встречается выражение «укрепление страны»:

«Надеюсь, что у вас будет еще не одна удача, которая в иелом будет укреплять нашу историю, будет укреплять нашу страну, потому что мы с вами хорошо понимаем 
и знаем, собственно говоря, вы ради этого, наверняка, и работаете, важна память. Это моральный долг перед погибшими, защищавиими нашу страну, нашу Родину. Не менее важно будущее страны, а оно не может быть без прошлого, в данном случае без герочческого прошлого нашей страны» [Путин (2) 2015].

Следует отметить, что и для В.В. Путина, и для Д.А. Медведева свойственна героизация всех советских солдат, погибших во время Второй мировой войны, независимо от их действий и обстоятельств гибели:

«Особые слова благодарности бойцам поисковых отрядов, которые восстанавливают для страны и для родных имена героев, с почетом предают земле останки павших солдат Великой Отечественной, ухаживают за воинскими мемориалами» [Путин 2012].

«До сих пор, благодаря поисковой работе, открываются имена павших героев» [Медведев (2) 2009].

Между тем отдельные высказывания Путина о поисковой работе отличаются от основной совокупности его заявлений: в них присутствуют идея справедливости по отношению к погибшим солдатам и память о войне как трагедии, предотвращающая ее повторение:

«Это очень важная, благородная и полезная работа. Надо вспомнить Льва Николаевича Толстого: "Ничего нет более противоестественного, чем война". Но самое естественное - помнить об этих трагедиях, с тем чтобы ничего подобного не повторялось. И, конечно, очень важно, чтобы справедливость восторжествовала в отнотении тех людей, которые, как Вы сейчас сказали, пропали без вести. Они не должны быть безвестными. Это работа, может, на все оставшиеся годы, на все оставшиеся времена. Народ всегда должен помнить» [Путин (1) 2017].

Таким образом, лейтмотивами властной риторики о поисковой работе являются «настоящий патриотизм», «героизм», «воспитание», «гордость Отечеством» и «укрепление страны». Власть дискурсивно встраивает поисковое движение в патриотическое воспитание граждан, формулируя смыслы поисковой работы в контексте милитаризованного патриотизма.

\section{Лейтмотивы и смыслы поисковиков}

В повседневном общении поисковики редко обсуждают значение своей работы, в экспедициях эти смыслы считаются чем-то само собой разумеющимся. Исключение составляют существующие в некоторых поисковых отрядах традиции «кружек» или «свечек» - общего разговора у костра в начале и конце экспедиции, 
когда каждому предоставляется возможность высказаться. При этом поисковики открыто говорят о целях и значении поиска в интервью (как исследовательских, так и для медиа), пишут об этом в социальных сетях.

Высказывания поисковиков отличаются от властной риторики, пересекаясь с ней лишь в редких случаях. Позиция государства в отношении военно-патриотического воспитания находит свое отражение в нарративах информантов, но в основном только тогда, когда речь заходит о начальных этапах включения в поисковую работу: «Пришла я туда, потому что мне была интересна патриотическая тематика, патриотическое направление» (жен. 1, 20 лет). Однако по мере погружения в поисковую работу ее смыслы изменяются: даже в течение относительно короткого времени, когда проводились интервью (на протяжении двух лет), мы можем видеть эти изменения в замечаниях информантов и в их текстах в социальных сетях. Поисковая деятельность на начальном этапе включения в нее окутана ореолом романтики и экстрима, и зачастую, по оценкам самих информантов, в поиск их приводят случай и желание проверить себя, испытать новые ощущения. Например, пост в социальной сети нашей информантки после одной из первых экспедиций был чрезвычайно эмоциональным, наполненным переживаниями в связи с новыми знакомствами, встречей с людьми, «<..> с которыми можно идти на край света. Зачем, спросите вы? За приключениями!» (жен., 18 лет).

Затем эмоциональная восторженность на фоне ощущений особой атмосферы поискового отряда постепенно снижается, начинает усиливаться рефлексия по поводу того, что делают поисковики, почему, что это дает в личном отношении:

«Меня привлекал туризм, палатки, все это. Я честно не понимала в первый раз, в первую свою экспедицию, зачем мне это было все нужно. Я думала, мы просто перезахораниваем останки» (жен. 2, 19 лет).

«Потом, уже находя и поднимая останки на воронке, я понял, что главная цель здесь не выжить, что-то приготовить на костре, а главная ичель - поднять бойца и найти медальон» (муж., 19 лет).

Знаковой оказывается именно первая экспедиция. «Сейчас я отношусь к этому не так, как в первый раз - романтика, вечера у костра, а именно как к работе, которой важно заниматься. Получается, эмочии отходят на второй план» (муж., 20 лет). После сильных эмоциональных переживаний первых недель жизни в лесу, непосредственного физического контакта с прошлым приходит другое восприятие поисковой работы, связанное с личным, субъективным осознанием войны:

«Mь поднимали девушку в воронке, уже опознали, что это девушка, и по черепу, и по тазу. А ведь все молодые были, всем до 35 лет. Как окопь ещуе рыли в такой земле под таким дождем, снегом, градом?» (жен. 2, 19 лет).

«Они лежат так 60-65 лет. Никому до них дела нет, и если ты не поедешь, они так и будут лежать. А читаешь про них: те же парни, по 23 года. Нашли там орден 
Красной Звезды -молодой парень. За собой ведет ичелое поколение героев. И так вот брошень в лесу» (муж., 29 лет).

«Поднимая останки солдата, они прожсивают каждую последнюю минуту его жизни вместе с ним. Они представляют, каким он был, находя его личные вещи: ложски и котелки, портсигары и мундитуки, звездочки и значки, медальоны и медали. Именно там, в лесах и болотах, на местах боев, они исправно дописывают личную историю своего солдата. Они хотят наконец-то поставить точку и вернуть своих бойцов с войны. Они хотят исправить ошибки прошлого и не допускать их впредь. Я ехала дальше и думала, что ответ-то на все мои вопросы прост: "Мы просто не хотим их больше предавать"» (жен., запись в социальной сети).

Идея патриотизма иногда используется поисковиками, но они противопоставляют ее патриотизму, демонстрируемому посредством широко распространенных символов:

«Стоять на захоронении, слышать залпы за спиной, видеть вытянутые спины, расправленные плечи и серьезные лица товарищей вокруг - это непередаваемые ощущения. И это есть часть настоящего патриотизма, а не георгиевская ленточка на сумочке или автомобиле ко Дню Победы. Не путайте, пожалуйста» (жен., 26 лет).

«Как у нас память выражается к этим павшим солдатам? Наклейка на машине “На Берлин!”. Или ленточка георгиевская где-нибудь на сумке или еще хуже - на кроссовках завязанная» (жен., 23 года).

По мнению поисковиков, значение имеют не громкие речи и официальные символы, а реальные дела и поступки: «Мы, поисковики, по сути - просто огромная похоронная команда, которая должна собирать на поле боя трупы солдат и хоронить их. Что мы и делаем» [Савельев 2017, с. 234].

Часть поисковиков не приемлет патриотическую риторику, определяя ее как «пафос», «громкие слова», «речи у микрофона», «выхолощенные понятия», «патриотизьм», «цинизм». Противопоставление своих действий государственному патриотическому дискурсу особенно отчетливо проявляется в связи с празднованием Дня Победы, официальными событиями, тем, каким образом чиновники участвуют в захоронении солдат и что при этом говорят:

«Довольно-таки плохо отношусь к тому, что вся волна патриотизма поднимается перед 9 мая, мне это не очень нравится. Они там во весь голос говорят о политике, а мне кажется, ты не должен во весь голос об этом рассказывать. Просто какое-то дело делай» (муж., 20).

«Когда происходит захоронение, тут же приезжают всякие чиновники, начинаются речи. Ты кому это все рассказываешь? Еще пафос выдают: "Вы занимаетесь таким 
хорошим святым делом”. Ты зачем нам это все говоришь? Мы здесь не ради этого, для нас это просто работа. Мы здесь не для того, чтобы ваши хвалебные речи слушать и принимать на свой счет, нам это даром не надо. И когда это все начинается, меня лично это раздражсает» (муж., 21 год).

"[О захоронении] Все, вроде, чин по чину, с воинскими почестями, как положено солдатам. Но ты туда не пойдешь, чтобы не видеть и не слымать свору "небожителей” всех чинов и рангов, которые слетаются попиариться на костях. Опережая друг друга, они будут изрыгать свою лживую патриотическую блевотину. Давно известный сиенарий. Тошно. Там нет жизни, там мертвые слова и глаза. "Не забудем... перед вами в неоплатном долгу... оказывать всемерную поддержку поисковому движению...”. Сказано и забыто» [Савельев 2017, с. 42-43].

Участники поисковых экспедиций часто говорят о несправедливости и предательстве по отношению к погибшим солдатам и о своей обиде за них:

«Мне хотелось несправедливость выровнять. Очень обидно, что о тех бойцах, которые там сейчас лежат, в принципе, забыли. И хочется восстановить память о них, вернуть хотя бы некоторых, кого возможно, домой, чтобы родственники хотя бы знали» (жен. 2, 20 лет).

«Знаете, что поражает? В книгах советского времени столько пафоса, столько лозунгов, мол, “никто не забыт и ничто не забыто”. Но вот лежат эти погибшие солдаты в воронках от снарядов. Чьи-то тела просто разбросаны по поверхности. Время прикрыло их только дерном. Обидно за своих!» [Иванова 2012, с. 140].

«Не можем мы без юмора в лесу. Это наша защитная реакция на это огромное в полстраны - кладбище, на эту жесточайшую несправедливость по отночению к погибшим и незахороненным бойцам, на ицнизм, вот в этом случае уже настоящий цинизм власть предержащих, когда с трибун сльшно одно, а на деле совсем другое» [Савельев 2017, с. 25].

«Мне обидно, что государство бросило их на произвол судьбы. Но была гордость, когда мы их хоронили. Не государство, так мы, поисковики, захоронили их с почестями» (Алексей Карпов) [Щербина 2016, с. 133].

«За плечами - 25 лет почсковой работы, но ответ на главный вопрос так и не появился. Почему в стране-победительнице солдаты брошены, и их до сих пор тысячи на местах боев?» [Щербина 2016, с. 9].

При этом поисковики отмечают равнодушие к незахороненным останкам солдат в послевоенное время со стороны не только властей, но и местных жителей. В рассказах участников поисковых экспедиций описываются как привыкание жителей к тому, что рядом лежат человеческие останки [Иванова 2012, с. 42, 106; 
Черепанов 2006, с. 57], так и многочисленные случаи, когда грунт с останками солдат сгребали и перепахивали бульдозерами и тракторами, воронки с останками использовались сельчанами как мусорные ямы [Щербина 2016, с. 17]. Более того, на месте братской могилы была построена свиноферма [Черепанов 2006, с. 62], а на месте падения самолета, где до сих пор находятся останки летчиков, - частный дом [Каюмов 2018].

«Когда началось освоение участков, один из хозяев при нас выбросил за забор гнилой валежник вперемешку с человеческими костями. А ведь кто-то до сих пор ищет могильг своих отцов и дедов» (Александр Чупров) [Иванова 2012, с. 157].

«[19:08] В 2011 и 2012 провели три экспедищии в урочищах Крутик, Любщы и Копџы, это между Мясным Бором и Подберезьем. Там неровности (гряды) были с останками солдат, как будто бульдозерами сгребали грунт. В нескольких десятках и сотнях метров от шоссе Москва - Санкт-Петербург, с восточной стороны. [19:29] Бульдозерами и сгребали. Там колея от гусении местами есть, и новгородиы подтвердили. [19:29] В 50-х годах поля расчищали и в ближайший лесок» (переписка в чате поискового отряда).

Чувство несправедливости обостряется на фоне усиливающейся коммеморативной риторики властей и репрезентации прошлого на уровне официальной памяти:

«Чем занимаюсь, к чему стремлюсь? Почему трачу время на эти дела, а не на другие? Чего хочу? А хочется справедливости. Государство не может оперировать мальми цифрами, оно мыслит миллионами. Зачем миллионам имена? Почти 30 млн погибших, из них почти 3 млн пропавщих без вести. Иногда эту цицру произносят с мрачной гордостью. Странно, да? Значимы ли эти люди? Конечно, ответит каждый. Они же герои, воевали за наше будущее. Но если так, то возникает вопрос: "Почему эти люди до сих пор не преданы земле со всеми воинскими почестями?”. И почему у этих людей нет имен? Почему у их родственников на руках извещения, что человек пропал без вести и о его судьбе ничего неизвестно? И до сих пор неизвестно. Получается, что на словах почести возданы, памятники поставлены, по факту - почти в каждой семье есть пропавший без вести, лежащий на поле боя, в безымянном братском захоронении, которого еще можно найти» (жен. 4., 20 лет, запись в социальной сети).

С лейтмотивом несправедливости связаны отрицательные и ироничные высказывания поисковиков о военно-патриотическом воспитании посредством поисковой работы:

«Вызывает сомнение, что молодой человек станет патриотом своей Родины, видя как Родина обходится со своими сынами» [Котилевский 2004, с. 12]. 
«Там, где "Вахта" большая - несколько десятков отрядов с разных областей и стран, - она превращается в карнавал. Сегодня у нас посвящение, завтра концерт, послезавтра экскурсия, а потом в баню... А работать когда? Некогда. Мы, видишь ли, детей привезли. Их воспитывать надо. Военно-патриотическое воспитание. И как-то забывается, что основная иель - искать и хоронить. Не, не! Детей возить на “Вахту”! Вот главная ијель сегодня поисковых организаций. Воспитание, ага... Это кладбище! Нельзя сюда детей возить. На экскурсии» [Ивакин 2010].

«Затрат много, хотя поисковая работа в России государством якобы финансируется. Может, до нас просто не доходит? Или мы не в том государстве живем? Хотя, вроде, в России. Тогда “где деньги, Зин?”. А-а, на патриотическое воспитание подрастающего поколения потрачены... На слеты, линейки, прочие мероприятия, юбилеи, соревнования. Понятно... Да ладно - чем бы дитя ни тешилось... Мы уж какнибудь сами» [Савельев 2017, с. 19].

Государственной милитаристской риторике дискурсивно противопоставляется проблематизация войны, основанная на опыте поисковой работы:

«Главное, чтоб не было войны... Война - это страшно» [Орлов 2018].

«Много философии в голову приходит. Вместе с дымящейся сигаретой. Каждый метр - солдат. Каждый метр - солдат. По всей стране. А я много где была. Ненавижу войну» [Щербина 2016, с. 73].

«Война - "это отчаяние, смерть, страх и сплетение нелепейшего бездумного прозябания с безмерными муками. Я вижу, что кто-то натравливает один народ на другой, и люди убивают друг друга, в безумном ослеплении покоряясь чужой воле, не ведая, что творят, не зная за собой виньл". Эрих Мария Ремарк» (Наталья Чернова, запись в социальной сети).

Отчетливый антивоенный смысл имеют многие исполняемые в экспедициях песни, авторы которых - как рок-музыканты и барды («Не стреляй» и «Пацаны» Юрия Шевчука и ДДТ, «Облака» и «Панамки» Вадима Егорова), так и сами поисковики:

«... Зачем случается война,

И кто о ней слагает мифы,

В которых логика солдата

Уместней слез, уместней стонов,

А жизнь людей-товар и плата

Эпохи фронтовых законов?..

Зачем случается война?

Вопрос не старый и не новый.
Уже давным-давно полна

Копилка опыта земного.

А человечество мое

Себе на стыл и удивленье

Все ставит, ставит под ружье

Очередные поколенья...»

(Владимир Ерхов,

«Прикосновение к войне»). 
Работа поисковиков в экспедициях, а также анализ воспоминаний ветеранов и архивных данных выявляют, какими огромными были потери в Красной армии, и каким пренебрежительным - отношение командования к жизни солдат и памяти о погибших:

«Наступая по железнодорожному полотну, 1015 сn [стрелковый полк] оставил в тылу противника своих раненых, о чем свидетельствует документ, хранящийся в ЦАМО [Центральном архиве Министерства обороны]: “...Штаб 285 сд [стрелковой дивизии]. При этом представляю именные списки безвозвратных потерь на рядовой и младиий начальствующий состав 1015 сn за январь 1942 г. на 263 чел. Задержка представления связана с тем, что полк, перейдя в январе 1942 г. линию ж/д и р. Жарок, оставил в тылу противника большую группу раненых в связи с невозможностью их эвакуировать. Установить судьбу 244 красноармейцев не представляется возможным, и они в списках указываются как пропавшие без вести”. Вот так, бросив в лютый январь на верную смерть раненых бойџов, их просто списывают как без вести пропавших» (Илья Прокофьев) [Иванова 2012, с. 213].

Со стремлением восстановить справедливость и похоронить солдат неразрывно связан другой смысл поисковой работы - возвращение памяти, оповещение родственников о судьбе солдата:

«Видно, что есть люди, которые до сих пор ждут кого-то. То есть в эти моменты понимаешь, что это кому-то надо. Даже если не тебе, то ты для кого-то это делаешь» (жен. 2., 19 лет).

«Я видел глаза и матерей и отцов, и братьев и сестер тех, кто там погиб. Это воодушевляло нас на поиски. Хотя многие нам говорили: "Ну, что вы ковыряетесь, это уже все забыто... И никому это не надо”. Но когда ты находишь медальон, в котором, по сути, хранится цеелая человеческая жизнь, такая вещица толкает людей снова и снова идти в лес. А когда ты откручиваешь медальон трясущимися руками, чтобы узнать, есть ли бумажка или нет... Если вкладыш в хорошем состоянии, - это такое счастье» [Орлов 2018].

Удача поисковиков, которая, по утверждению В.В. Путина, укрепляет нашу страну, понимается ими самими совсем иначе. Удача для них - это обнаружение медальона с читаемым вкладышем, сохранившейся красноармейской книжки, подписанной солдатом личной вещи, установление имени солдата, успешный поиск родственников, но это кроме радости связано и с пониманием трагедии семей:

«[23:27] Поговорил сегодня с Надеждой Васильевной еще раз. Рассказал, что решение о том, где будет похоронен солдат, принимают родственники. В семье Надежды Васильевны обсуждали вариант с похоронами в Петербурге, но в конце концов она 
решила, что будет лучше, если он будет похоронен на воинском мемориале в Мясном Бору вместе с теми, с кем воевал и погиб. Это не так далеко от Петербурга. Насколько я понял, беспокоит ее, что погребение состоится только через год, 8 мая 2020 года. Припоминает Надежда Васильевна, что кто-то из тех, кто воевал вместе с ним, рассказал позже Анне Яковлевне, матери Василия Иосифовича, что всемером они ушли в разведку и не вернулись. Анна Яковлевна очень ждала сына, плакала, говорила внучке: "Если бы он вернулся”, ходила по деревням, спрашивала о нем тех, кто вернулся с войны. “Слезы-слезы все время”. В какой-то момент, спустя два-три года после освобождения деревни (или окончания войны??), стали возвращаться пленные. И с этим была связана надежда, что остался жив, вернется. [23:37] Кажется, что-то нужно написать, а внутри такая тишина. Сколько трагедии в истории одной семьи, сколько ещзе таких трагедий было» (переписка в чате поискового отряда о разговоре с дочерью солдата, пропавшего без вести и найденного поисковиками спустя 77 лет).

\section{Заключение}

Лейтмотивы властной риторики о поисковой работе («настоящий патриотизм», «воспитание», «героизм», «гордость Отечеством» и «укрепление страны») значительно отличаются от утверждений поисковиков. При этом смыслы патриотизма и гордости за Отечество применительно к поисковой работе, формируемые Кремлем, оказываются в противоречии с высказываниями о несправедливости, характерными для участников экспедиций. В основе этого противоречия лежит вопрос о том, почему столь долгое время, на протяжении десятилетий, Отечество, к любви к которому и гордости за которое призывают власти, оставалось равнодушным к незахороненным останкам солдат.

Утверждения президентов России о поисковой работе указывают на то, что она интересует власти прежде всего с точки зрения ее воспитательного воздействия. Между тем результаты исследования ставят под сомнение возможность вклада поисковиков в патриотическое воспитание граждан в том виде, в каком оно понимается российскими властями. Часть поисковиков использует понятие патриотизма, но наполняет его другим содержанием, отличным от интерпретации Кремля. Другая часть полностью отвергает патриотическую риторику и критически высказывается о воспитательном эффекте поисковой работы. Различия с властным дискурсом связаны также со свойственной поисковикам проблематизацией войны, основанной на опыте экспедиций, который выявляет огромные потери и часто бесчеловечное отношение командования к живым и погибшим солдатам. Высказывания поисковиков о войне оказываются в противоречии с милитаризованной версией патриотизма, конструируемой властями.

Сцена поискового движения неоднородна: с одной стороны, для нее характерна солидарность, с другой, разнонаправленные внутренние самоорганизации, и активное вовлечение поискового движения в государственный дискурс и работу с молодежью лишь усиливает эту дифференциацию. Мы охватили лишь часть высказываний поисковиков об их работе: существует множество текстов в виде тезисов выступлений на конференциях и статей в сборниках, в которых 
воспроизводятся лейтмотивы патриотизма и воспитания в отношении поисковой работы. Как правило, эти тексты написаны руководителями поисковых штабов, региональных объединений и отрядов, которые находятся с властями в тех или иных отношениях, включая получение грантов. Наше исследование показывает разнообразие поискового движения и выявляет существенные различия между смыслами поисковой работы, формулируемыми поисковиками и властями.

Спустя почти восемь десятилетий после войны находить незахороненные останки становится все труднее, поисковики все чаще, по их словам, занимаются «фрагментами» или «добором» ${ }^{8}$. Между тем поисковые функционеры - руководители Поискового движения России - активно используют открывающиеся грантовые возможности, предполагающие наличие проекта, новизны и заметных результатов. При объяснении актуальности и значимости таких проектов, например, проекта «Без срока давности» о массовой гибели в годы Второй мировой войны мирных граждан функционеры используют конструкты Кремля: «фальсификация истории» и «героизация нацизма». В настоящее время поисковое движение политизируется собственным руководством: «Люди, которые фальсифицируют историю, хотят одного - они хотят гибели нашего государства. Стреляя в наше прошлое, они стреляют в наше будущее. Поэтому так важно делать наше дело правильно, проводить поисковые работы, фиксируя все детали. Это наша передовая, это наш поисковый фронт» (Елена Цунаева) [На семинаре «Поисковый фронт» 2016]. В связи с этим одним из направлений дальнейшего исследования может стать анализ риторики функционеров, политизации и дифференциации поискового движения. Мы предполагаем, что в ближайшие годы Кремль и поисковые функционеры будут интенсивно использовать политизированную и милитаризованную идею патриотизма применительно к поисковому движению, что будет способствовать дальнейшему росту противоречий и делений в нем.

\section{Литература}

Берестов С.А. (ред.) (2018) Дом. О войне после войны. Сборник рассказов (Серия «Антология поискового рассказа»). Рязань: Зерна-Слово.

Ибарра П., Китсьюз Дж. (2007) Дискурс выдвижения утверждений-требований и просторечные ресурсы // Ясавеев И.Г. (сост.) Социальные проблемы: конструкционистское прочтение. Казань: Изд-во Казанск. ун-та. С. 55-114.

Ивакин А. (2010) Я живу в ту войну. Поисковые рассказы // Okopka.ru. 25 февраля 2010 // http://okopka.ru/i/iwakin_a_g/text_0040.shtml

Иванова И.А. (ред.) (2012) Простите нас, солдаты... Сборник очерков о работе молодежных поисковых отрядов Санкт-Петербурга. СПб.: Вести.

Каюмов Н. (2018) Дом // Берестов С. А. (ред.) Дом. О войне после войны. Сборник рассказов. Серия «Антология поискового рассказа». Рязань: Зерна-Слово. С. 213-223.

Комендант «Долины смерти» (2013). Сборник [посвящ. Н.И. Орлову]. Великий Новгород. Котилевский С.С. (2004) Теория и практика поисковых работ. Казань: Отечество.

\footnotetext{
8 «Добор» в методических документах Поискового движения России определяется как «отдельные или фрагментарные человеческие костные останки, обнаруженные на местах бывших раскопов, произведенных неустановленными лицами, а также ампутированные, оторванные, принесенные животными или вытаявшие из ледника человеческие кости» [Протокол эксгумации 2016].
} 
Медведев Д.А. (1) (2009) Встреча с членами молодежного поискового центра «Искатель» // Президент России. 11 марта 2009 // http://www.kremlin.ru/events/president/transcripts/3399

Медведев Д.А. (2) (2009) Выступление на военном параде в честь 64-й годовщины Победы в Великой Отечественной войне // Президент России. 9 мая 2009 // http://www.kremlin.ru/events/president/transcripts/4015

Медведев Д.А. (2010) Послание Президента Федеральному Собранию // Президент России. 30 ноября 2010 // http://www.kremlin.ru/events/president/news/9637

На семинаре «Поисковый фронт» состоялась лекция по противодействию фальсификации истории (2016) // Поисковое движение России. 8 июля 2016 // http://rf-poisk.ru/news/1757

Неоконченная война (2005). Диск, посвященный 60-летию Победы и открытию Всероссийской Вахты Памяти-2005 в Великом Новгороде. Поисковая экспедиция «Долина» памяти Н.И. Орлова. 1 электрон. опт. диск (CD-ROM).

Общероссийское общественное движение по увековечению памяти погибших при защите Отечества (2019) // Поисковое движение России // http://rf-poisk.ru/page/230

Омельченко Д.А. (2017) Любань. Документальный фильм // https://youtu.be/ZoZHrWNu5_E

Омельченко Е.Л. (2012) Как научить любить Родину? Дискурсивные практики патриотического воспитания молодежи // Омельченко Е., Пилкингтон Х. (ред.) С чего начинается Родина: молодежь в лабиринтах патриотизма. Ульяновск: УлГУ. С. 261-310.

Орлов А.Н. (2018) Вся радость - в прочитанном медальоне // Область культуры // http://okultureno.ru/articles/30147-aleksandr-orlov-vsya-radost-v-prochitannom-medalone

Протокол эксгумации (2016) // Поисковое движение России. 18 мая 2016 // http://rf-poisk.ru/documents/131/

Путин В.В. (2003) Беседа с финалистами конкурса «Мой дом, мой город, моя страна» // Президент России. 5 июня 2003 // http://www.kremlin.ru/events/president/transcripts/22021

Путин В.В. (2012) Послание Президента Федеральному Собранию // Президент России. 12 декабря 2012 // http://www.kremlin.ru/events/president/news/17118

Путин В.В. (2014) Участникам и гостям съезда поисковиков России // Президент России. 14 марта 2014 // http://www.kremlin.ru/events/president/letters/20532

Путин В.В. (1) (2015) Открытие всероссийской акции «Вахта памяти» // Президент России. 6 апреля $2015 / / \mathrm{http}: / \mathrm{kremlin} . r u /$ events/president/news/49204

Путин В.В. (2) (2015) Встреча с ветеранами Великой Отечественной войны и участниками Поискового движения России // Президент России. 6 апреля 2015 // http://kremlin.ru/events/president/news/49207

Путин В.В. (1) (2017) Встреча с участниками Форума лидеров студенческих и молодежных организаций // Президент России. 25 января 2017 // http://www.kremlin.ru/events/president/news/53772

Путин В.В. (2) (2017) Участникам торжественного мероприятия, посвященного открытию Всероссийской акции «Вахта памяти-2017» // Президент России. 5 апреля $2017 / /$ http://www.kremlin.ru/events/president/letters/54215

Путин В.В. (1) (2018) Посещение музея-панорамы «Прорыв» // Президент России. 18 января $2018 / /$ http://kremlin.ru/events/president/news/56666

Путин В.В. (2) (2018) Встреча с представителями поискового движения России и ветеранами Великой Отечественной войны // Президент России. 23 августа 2018 // http://www.kremlin.ru/events/president/news/58358

Путин В.В. (3) (2018) Заседание дискуссионного клуба «Валдай» // Президент России. 18 октября $2018 / /$ http://www.kremlin.ru/events/president/news/58848

Путин В.В. (2019) Открытие всероссийской акции «Вахта памяти - 2019»// Президент России. 4 апреля 2019 // http://kremlin.ru/events/president/news/60222

Рождественская Е., Семенова В. (2011) Социальная память как объект социологического изучения // INTER. № 6. С. 27-48.

Савельев А. (2017) Похоронная команда. Рыбинск: Рыбинский Дом печати.

Савельев А., Пицко П. (2015) Диагноз - поисковик. Сборник рассказов. СПб.: БИОНТ.

Указ Президента Российской Федерации № 190 (2013) // Президент России. 12 марта 2013 // http://www.kremlin.ru/acts/bank/36864 
Черепанов М.В. (2006) Зачем живым Долина смерти? К 25-летию поисковых экспедиций татарстанцев. Казань: Хэтер.

Щербина Л. (2016) Прикоснувшись к войне. Казань: Центр инновационных технологий.

Ясавеев И.Г. (2016) Лейтмотивы властной риторики в отношении российской молодежи // Социологическое обозрение. Т. 15. № 3. С. 49-67.

Dahlin J. (2017) 'No one is Forgotten, Nothing Is Forgotten': Duty, Patriotism, and the Russian Search Movement // Europe-Asia Studies, vol. 69, no 7, pp. 1070-1089.

Dahlin J. (2018) Labour of Love and Devotion? The Search for the Lost Soldiers of Russia // Emotion, Affective Practices, and the Past in the Present (eds. Smith L., Wetherell M., Campbell G.), New York: Routledge, pp. 25-38.

Laruelle M. (2015) Patriotic Youth Clubs in Russia. Professional Niches, Cultural Capital and Narratives of Social Engagement // Europe-Asia Studies, vol. 67, no 1, pp. 8-27.

\title{
The Meanings of WW2 Search Work in Russia in the Rhetoric of State Authorities and the Searchers Themselves ${ }^{9}$
}

\author{
N. GONCHAROVA*, I. YASAVEEV**
}

\begin{abstract}
*Natalia Goncharova - PhD in Sociology, Researcher, Centre for Youth Studies, National Research University Higher School of Economics in Saint-Petersburg. Address: 55, bldg 2, Sedova St., Saint Petersburg, 192148, Russian Federation. E-mail: nata gonch@mail.ru **Iskender Yasaveev - DSc in Sociology, Senior Researcher, Centre for Youth Studies, National Research University Higher School of Economics in Saint Petersburg. Address: 55, bldg 2, Sedova St., Saint Petersburg, 192148, Russian Federation. E-mail: yasaveyev@gmail.com
\end{abstract}

Citation: Goncharova N., Yasaveev I. (2020) The Meanings of WW2 Search Work in Russia in the Rhetoric of State Authorities and the Searchers Themselves. Mir Rossii, vol. 29, no 1, pp. 153-173 (in Russian). DOI: 10.17323/1811-038X-2020-29-1-153-173

\begin{abstract}
This article focuses on the meanings of search work in Russia, i.e. the search for and identification of the unburied remains of Soviet soldiers who perished in WW2. These meanings are constructed not only by the participants of expeditions (or poiskoviki, as they call themselves), but also by the Russian authorities, who actively support this movement. To reconstruct these meanings, we rely on several different sources: the addresses of Russia's presidents to the search movement, participant observations as part of expeditions, interviews with their members and texts by the searchers themselves in the form of books, stories, songs and blog posts in social media.

\footnotetext{
9 The study was carried out within the project "Creative Fields of Interethnic Interaction and Youth Cultural Scenes of Russian Cities" supported by Russian Science Foundation (grant no. 15-18-00078).
} 
The rhetoric of the state authorities as regards the movement is filled with elevated sentiments like "patriotism", "heroism", "education", "pride for the Fatherland", and "national consolidation". They tend to discursively embed it in the patriotic education of Russian citizens, formulating the meanings of the search in the context of militarized patriotism. The search work is presented by the president as a demonstration of "genuine patriotism", which consists in defending the country with arms and self-sacrifice. Searchers' statements about their work are colored with motives of a different tone, such as the sense of unfairness towards the soldiers who have remained unburied for decades. Some members of the movement reject the patriotic rhetoric and critically contest the educational effect of their work. The desire to restore fairness by burying the remains and informing the relatives about the fate of missing soldiers is the basic meaning of the searches according to the participants. A successful search is thought to contribute to the understanding of the tragedy of a family that lost loved ones in the war. The problematization of the war in the searchers' experiences is discursively and explicitly contrasted with the authorities' militaristic rhetoric.

Key words: search movement, poiskoviki, Russian authorities, power, patriotism, youth, war, memory work

\section{References}

Berestov S. (ed.) (2018) Dom. O vojne posle vojny [The House. On the War and the War Aftermath], Ryazan': Zerna-Slovo.

Cherepanov M. (2006) Zachem zhivym Dolina smerti? [The Relevance of the Death Valley to the Living?], Kazan: Hjeter.

Dahlin J. (2017) 'No One is Forgotten, Nothing Is Forgotten': Duty, Patriotism, and the Russian Search Movement. Europe-Asia Studies, vol. 69, no 7, pp. 1070-1089.

Dahlin J. (2018) Labour of Love and Devotion? The Search for the Lost Soldiers of Russia. Emotion, Affective Practices, and the Past in the Present (eds. Smith L., Wetherel M., Campbell G.), New York: Routledge, pp. 25-38.

Ibarra P.R., Kitsuse J.I. (2007) Diskurs vydvizhenija utverzhdenij-trebovanij i prostorechnye resursy [The Claims-Making Discourse and Vernacular Resources]. Sotsial'nye problemy: konstruktsionistskoe prochtenie [Social Problems: a Constructionist Reading] (ed. Yasaveev I.), Kazan: Izd-vo Kazansk. un-ta, pp. 55-114.

Ivakin A. (2010) Ya zhivu v tu vojnu [I Live That War]. Okopka.ru, February 25, 2010. Available at: http://okopka.ru/i/iwakin_a_g/text_0040.shtml, accessed 31.10.2019.

Ivanova I. (ed.) (2012) Prostite nas, soldaty... [Forgive Us, Soldiers...], Saint Petersburg: Vesti.

Kayumov N. (2018) Dom [The House]. Dom. O vojne posle vojny [The House. On the War and the War Aftermath] (ed. Berestov S.), Ryazan': Zerna-Slovo, pp. 213-223.

Komendant «Doliny smerti» [The Commandant of the Death Valley] (2013), Velikij Novgorod.

Kotilevskij S. (2004) Teoriya i praktika poiskovykh rabot [The Theory and Practice of the Search Work], Kazan': Otechestvo.

Laruelle M. (2015) Patriotic Youth Clubs in Russia. Professional Niches, Cultural Capital and Narratives of Social Engagement. Europe-Asia Studies, vol. 67, no 1, pp. 8-27.

Medvedev D. (1) (2009) Vstrecha s chlenami molodezhnogo poiskovogo tsentra «Iskatel» [Meeting with the Members of the Youth Search Work Center "Iskatel"']. President of Russia, March 11, 2009. Available at: http://www.kremlin.ru/events/president/transcripts/3399, accessed 31.10.2019. 
Medvedev D. (2) (2009) Vystuplenie na voennom parade v chest' 64-j godovshchiny Pobedy v Velikoj Otechestvennoj vojne [Speech at the Military Parade to Honor the 64th Anniversary of the Victory in the Great Patriotic War]. President of Russia, May 9, 2009. Available at: http://www.kremlin.ru/events/president/transcripts/4015, accessed 31.10.2019.

Medvedev D. (2010) Poslanie Prezidenta Federal'nomu Sobraniju [Presidential Address to the Federal Assembly of the Russian Federation]. President of Russia, November 30, 2010. Available at: http://www.kremlin.ru/events/president/news/9637, accessed 31.10.2019.

$\mathrm{Na}$ seminare «Poiskovyj front» sostoyalas' lektsiya po protivodejstviyu fal'sifikatsii istorii [Lecture on the Countering the Falsification of History Delivered at the "Search Front" Seminar] (2016). Poiskovoe dvizhenie Rossii [The Search Movement of Russia], July 8, 2016. Available at: http://rf-poisk.ru/news/1757, accessed 31.10.2019.

Neokonchennaya vojna [The Unfinished War. Electronic Optical Disk (CD-ROM) dedicated to the 60th Anniversary of the Victory and the Opening of the All-Russian Memory Watch-2005] (2005), Velikij Novgorod: Poiskovaya ekspeditsiya "Dolina" pamyati N.I. Orlova.

Obshcherossijskoe obshchestvennoe dvizhenie po uvekovecheniyu pamyati pogibshikh pri zashchite Otechestva [The All-Russian Social Movement to Perpetuate the Memory of Those Killed in the Defense of the Fatherland] (2019). Poiskovoe dvizhenie Rossii [Search Work Movement in Russia]. Available at: http://rf-poisk.ru/page/230, accessed 31.10.2019.

Omelchenko D. (2017) Lyuban'. Dokumental'nyj fil'm [Lyuban. A Documentary]. Available at: https://youtu.be/ZoZHrWNu5 E, accessed 31.10.2019.

Omelchenko E. (2012) Kak nauchit' lyubit' Rodinu? Diskursivnye praktiki patrioticheskogo vospitaniya molodezhi [How to Teach to Love Motherland? The Discursive Practices of Patriotic Training of Youth]. S chego nachinaetsya Rodina: molodezh'v labirintakh patriotizma [Where Motherland Begins: Youth in the Labyrinths of Patriotism] (eds. Omelchenko E., Pilkington H.), Ul'yanovsk: UISU, pp. 261-310.

Orlov A. (2018) Vsya radost' - v prochitannom medal'one [All Joy Is in the Medallion that Is Read]. Oblast' kul'tury [The Region of Culture]. Available at: http://okultureno.ru/articles/30147aleksandr-orlov-vsya-radost-v-prochitannom-medalone, accessed 22.06.2018.

Protokol eksgumatsii [Exhumation Protocol] (2016). Poiskovoe dvizhenie Rossii [Search Work Movement in Russia]. Available at: http://rf-poisk.ru/documents/131/, accessed 31.10.2019.

Putin V. (2003) Beseda s finalistami konkursa «Moj dom, moj gorod, moya strana» [Meeting with the Finalists of the Student Essay Competition "My Home, My City, My Country"]. President of Russia, June 5, 2003. Available at: http://www.kremlin.ru/events/president/transcripts/22021, accessed 31.10.2019.

Putin V. (2012) Poslanie Prezidenta Federal'nomu Sobraniyu [Presidential Address to the Federal Assembly]. President of Russia, December 12, 2012. Available at: http://www.kremlin.ru/events/president/news/17118, accessed 31.10.2019.

Putin V. (2014) Uchastnikam i gostyam s'ezda poiskovikov Rossii [To the Participants and Guests of the Congress of Russian Searchers]. President of Russia, March 14, 2014. Available at: http://www.kremlin.ru/events/president/letters/20532, accessed 31.10.2019.

Putin V. (1) (2015) Otkrytie vserossijskoj aktsii "Vakhta pamyati" [Opening of the "Memory Watch" National Commemorative Event]. President of Russia, April 6, 2015. Available at: $\mathrm{http} / / \mathrm{kremlin} . \mathrm{ru} / \mathrm{events} / \mathrm{president} / \mathrm{news} / 49204$, accessed 31.10.2019.

Putin V. (2) (2015) Vstrecha s veteranami Velikoj Otechestvennoj vojny i uchastnikami Poiskovogo dvizheniya Rossii [Meeting with Great Patriotic War Veterans and the Members of Russian Search Work Movements]. President of Russia, April 6, 2015. Available at: http://kremlin.ru/events/president/news/49207, accessed 31.10.2019.

Putin V. (1) (2017) Vstrecha s uchastnikami Foruma liderov studencheskikh i molodezhnykh organizatsij [Meeting with the Participants of the Forum of Student and Youth Organization Leaders]. President of Russia, January 25, 2017. Available at: http://www.kremlin.ru/events/president/news/53772, accessed 31.10.2019.

Putin V. (2) (2017) Uchastnikam torzhestvennogo meropriyatiya, posvyashhennogo otkrytiyu Vserossijskoj aktsii «Vakhta pamyati-2017» [To the Participants of the Solemn Event 
Dedicated to the Opening of the All-Russian Event "Memory Watch-2017"]. President of Russia, April 5, 2017. Available at: http://www.kremlin.ru/events/president/letters/54215, accessed 31.10.2019.

Putin V. (1) (2018) Poseshchenie muzeya-panoramy «Proryv» 18 janvarja 2018 [Visiting the Proryv Panorama Museum]. President of Russia, January 18, 2018. Available at: $\mathrm{http} / / \mathrm{kremlin} . \mathrm{ru} / \mathrm{events} / \mathrm{president} /$ news/56666, accessed 31.10.2019.

Putin V. (2) (2018) Vstrecha s predstavitelyami poiskovogo dvizheniya Rossii i veteranami Velikoj Otechestvennoj vojny [Meeting with the Members of Russia's Search Work Movement and the Great Patriotic War Veterans]. President of Russia, August 23, 2018. Available at: http://www.kremlin.ru/events/president/news/58358, accessed 31.10.2019.

Putin V. (3) (2018) Zasedanie diskussionnogo kluba «Valdaj» [Meeting of the Valdai International Discussion Club]. President of Russia, October 18, 2018. Available at: http://www.kremlin.ru/events/president/news/58848, accessed 31.10.2019.

Putin V. (2019) Otkrytie vserossijskoj aktsii «Vakhta pamyati-2019»[Opening of Memory Watch 2019 National Event]. President of Russia, April 4, 2019. Available at: http://kremlin.ru/events/president/news/60222, accessed 31.10.2019.

Rozhdestvenskaya E., Semenova V. (2011) Sotsial'naya pamyat' kak ob'ekt sotsiologicheskogo izuchenya [Social Memory as an Object of Sociological Study]. INTER, no 6, pp. 27-48.

Saveliev A. (2017) Pokhoronnaya komanda [The Burial Team], Rybinsk: Rybinskij Dom pechati.

Saveliev A., Picko P. (2015) Diagnoz - poiskovik [Diagnosed as Poiskovik], Saint Petersburg: BIONT.

Shcherbina L. (2016) Prikosnuvshis' $k$ vojne [Having Touched the War], Kazan: Tsentr innovatsionnykh tekhnologij.

Ukaz Prezidenta Rossijskoj Federatsii № 190 (2013) [Decree of the President of the Russian Federation No. 190]. President of Russia, March 12, 2013. Available at: http://www.kremlin.ru/acts/bank/36864, accessed 31.10.2019.

Yasaveev I. (2016) Lejtmotivy vlastnoj ritoriki v otnoshenii rossijskoj molodezhi [The Government Rhetoric on Youth in Russia]. The Russian Sociological Review, vol. 15, no 3, pp. 49-67. 